\title{
International Comparison Test in Asia-Pacific Region for Impulse Voltage Measurements
}

\author{
Takayuki Wakimoto Member (Nippon Institute of Technology) \\ Masaru Ishii Senior Member (The University of Tokyo) \\ Hisashi Goshima Member (Central Research Institute of Electric Power Industry) \\ Etsuhiro Hino Member (Mitsubishi Electric Corporation) \\ Hiroyuki Shimizu Member (Nippon Institute of Technology) \\ Yi Li Non-member (National Measurement Institute) \\ Kim Ik-Soo Non-member (Korea Electrotechnology Research Institute)
}

Keywords: impulse voltage measurement, traceability, international comparison test

\section{Introduction}

The national standard class divider for the lightning impulse voltage measurements in Japan was developed in 1998. After three years, the standard impulse voltage calibrator was manufactured, too. These standard equipments are used as an industrial standard, and the performance had been evaluated annually supported by Ministry of Economy, Trade and Industry (METI). The standard impulse measuring system including the standard divider participated in the worldwide comparison test and its good performance was confirmed in 1999. Another international comparison test was carried out among three countries in the Asia-Pacific region in 2004 again and the standard measuring system participated in the test.

In this paper, the details and the results of the international comparison tests in 2004 are described.

\section{Comparison Test Method}

2.1 Participation Laboratory Five Laboratories, Nippon Institute of Technology (NIT), National Measurement Institute (NMI) Australia, Korea Electrotechnology Research Institute (KERI), Central Research Institute of Electric Power Industry (CRIEPI) and Mitsubishi Electric Corporation (MITSUBISHI), participated to the comparison test. NIT has a national standard class measuring system in Japan. CRIEPI and MITSUBISHI have a reference measuring system according to IEC-60060-2. Both measuring systems have the traceability with NIT system.

Therefore, the international comparison tests were carried out by moved MITSUBISHI and CRIEPI system to abroad.

2.2 Testing Voltages and Waves The international comparison had two test schemes which are the high voltage range (from $80 \mathrm{kV}$ to $400 \mathrm{kV}$ ) and the low voltage range (from $10 \mathrm{~V}$ to $500 \mathrm{~V})$. The wave shapes of the high voltage range test had the lightning impulse voltage (0.84/60 impulse and $1.56 / 60$ impulse). In the low voltage range test, we added the switching voltage wave shapes (20/4000 impulse and 250/2500 impulse) in addition to the lightning impulse voltage.

\section{Comparison Test Result}

3.1 High Voltage Test Figure 1 is a comparison test results of the peak value in the high voltage range tests. The difference between NIT and NMI are about $0.5 \%$. The time parameters showed the difference up to $4.2 \%$.

3.2 Low Voltage Test The low voltage test result of the

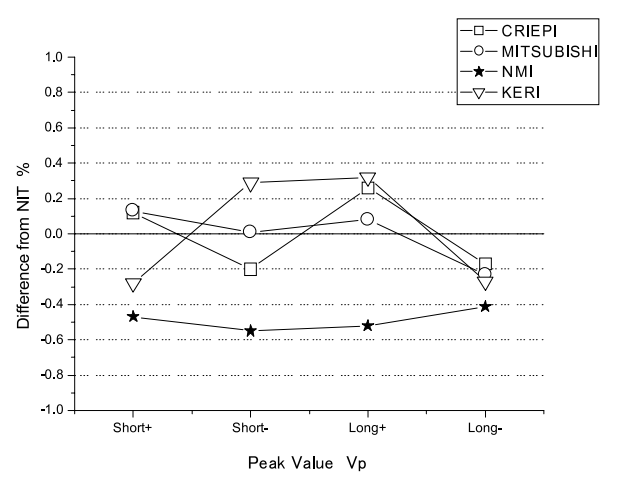

Fig. 1. Wave parameter differences deduced from high voltage comparison test results $(\mathrm{NIT}=1)$

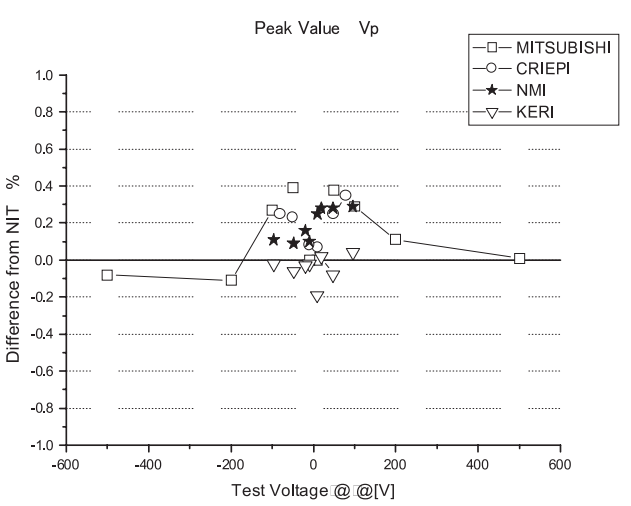

Fig. 2. Comparison test result at low voltage (lightning impulse) $(\mathrm{NIT}=1)$

peak value is shown in Fig. 2. As same with the result of the high voltage test, the difference between NIT and NMI had about $0.5 \%$.

\section{Conclution}

The differences of the wave parameter among three laboratories in Asia-Pacific region were clarified through the comparison test of the standard impulse voltage measuring system. The compatibility between NIT and NMI was confirmed by the results of the comparison and their measurement uncertainty. 


\title{
インパルス電圧測定系のアジア・太平洋地域国際比較試験
}

\author{
正 員 脇本 隆之* 上級会員 石井 勝** \\ 正員五島 久司 ${ }^{* * *}$ 正 員 日野 悦弘**** \\ 正員 清水 博幸* 非会員 $\mathrm{Yi} \mathrm{Li}^{* 5}$ \\ 非会員 Kim Ik-Soo*6
}

\section{International Comparison Test in Asia-Pacific Region for Impulse Voltage Measurements}

Takayuki Wakimoto*, Member, Masaru Ishii**, Senior Member, Hisashi Goshima***, Member,

Etsuhiro Hino ${ }^{* * * *}$, Member, Hiroyuki Shimizu*, Member, Yi Li ${ }^{* 5}$, Non-member, Kim Ik-Soo*6, Non-member

The national standard class divider for the lightning impulse voltage measurements in Japan was developed in 1998. After three years, the standard impulse voltage calibrator was manufactured, too. These standard equipment are used as an industrial standard, and the performance had been evaluated annually supported by Ministry of Economy, Trade and Industry (METI). The standard impulse measuring system including the standard divider participated in the worldwide comparison test and its good performance was confirmed in 1999. Another international comparison test was carried out among three countries in the Asia-Pacific region in 2004 again and the standard measuring system participated in the test.

In this paper, the details and the results of the international comparison tests in 2004 are described.

キーワード：インパルス電圧測定，トレーサビリテイ，国際比較試験

Keywords: impulse voltage measurement, traceability, international comparison test

\section{1. はじめに}

わが国の基準となる性能を有するインパルス電圧測定用 標準分圧器が 1998 年に製作された ${ }^{(1) \sim(3)}$ 。翌 1999 年には 22 カ国 23 機関がヘルシンキ工科大学の主催するインパル ス電圧の国際巡回比較試験に参加したが, わが国からもこ

\footnotetext{
*日本工業大学

干 345-8501 埼玉県宮代町 4-1

Nippon Institute of Technology

4-1, Miyashiro, Saitama 345-8501

** 東京大学

干 153-8505 東京都目黒区駒場 4-6-1

The University of Tokyo

4-6-1, Komaba, Meguro-ku, Tokyo 153-8505

*** (財) 電力中央研究所

干 240-0196 横須賀市長坂 2-6-1

Central Research Institute of Electric Power Industry

2-6-1, Nagasaka, Yokosuka 204-0196

**** 三菱電機 (株)

干 678-0256 赤穂市天和 651

Mitsubishi Electric Corporation

651, Tenwa, Ako 678-0256

*5 National Measurement Institute

Bradfield Road, West Lindfield, NSW 2070, Australia

*6 Korea Electrotechnology Research Institute

P.O.Box 20, Changwon, 641-600, Korea
}

の分圧器を主軸とする標準測定系を構築して試験を実施し た ${ }^{(4)}$ 。その結果，わが国のインパルス測定系及び技術力が 各国の国家標準と同等レベルにあることを確認することが できた。

一方国内においても，主要機関による巡回比較試験が幾 度か実施されており ${ }^{(5) \sim(7)}$ ，この面から見るとわが国のイン パルス電圧のトレーサビリティ体系は前述した標準測定系 を頂点として完成されているとみなしてもよい。

この標準測定系は現在産業界標準として国家標準レベル の扱いで運用されており，製作時に実施した性能試験をは じめとして, 毎年の長期安定性試験実施による安定性の検 証など，測定の不確かさの積み上げに必要な様々なデー夕 を蓄積しつつある。さらに毎年国内の主要機関に対してト レーサビリティ維持のための校正試験を実施し, 有効に運 用されている。

本測定系を我が国の最上位に位置する測定系と確認する ためには, 上述の性能維持の確認試験ばかりではなく, 諸外 国の保有する国家標準との同等性（コンパチビリティ）を 定期的に検証する必要がある。1999 年の国際比較試験時に も検証されたが，2004 年には日本がコーディネータとなっ てアジア・太平洋地域の国家標準級研究所 2 機関 (NMI : オーストラリア，KERI：大韓民国）とで国際比較試験を計 
画し，その実施に成功した。これにより，互いの国が所有 する標準級測定系の性能を確認するとともに長期安定性お よび同等性を検証することができた。このことは，アジア・ 太平洋地域において本分野でわが国が中心的な役割を担う 目的に向けて果たした意義はたいへん大きいといえる。

本論文は，この国際比較試験についてその内容及び結果 を述べるとともに，この試験を通じて得られた測定系の測 定の不確かさを推定し, 標準測定系の性能について検討し たものである。

\section{2. 試験概要}

$\langle\mathbf{2} \cdot \mathbf{1}\rangle$ 試験方法国際比較試験は Table 1 に試験内 容一覧を示すように，高電圧 $(80 \sim 400 \mathrm{kV})$ および低電圧 $(10 \sim 500 \mathrm{~V})$ の 2 種類の電圧範囲で実施した。高電圧試験 では， $0.84 / 60 \mu \mathrm{s}$ (short) ならびに $1.56 / 60 \mu \mathrm{s}$ (long) の 2 種類の雷インパルス電圧波形を用い，比較校正試験ならび に直線性試験を実施した。これらの試験には標準測定系と トレーサビリティを有する国内基準測定系を 2 系統用意し, それらを媒介測定系として NMI および KERIにて試験を 実施した。また媒介測定系が試験期間内でその性能に変化 がないことを確認するために輸送の前後で標準測定系との 比較試験を中心とした性能点検を実施するとともに，海外 機関への搬入及び搬出時には直流スケールファクタを確認 している。

低電圧試験では，2 種類の雷インパルス電圧波形のほか に250/2500 $\mu \mathrm{s}$ および $20 / 4000 \mu \mathrm{s}$ の開閉インパルス電圧波 形を追加し，全部で 4 種類の波形で試験を行った。お互い が所有する低電圧校正器をそれぞれ相手方の測定器に印加 し，算出される波形パラメータを比較評価する方法を用い た。なお，KERIは自所の校正器を所有しておらず，測定 器はNMI からトレースを取っている。

$\langle\mathbf{2 \cdot 2 \rangle}$ 各機関の測定システム Table 2 に各機関の測 定システムの概要を示す。日本工業大学（NIT）では 1998 年に製作した国家標準級分圧器を管理運用していて，同所 が保有する分解能 12 ビット, サンプリングレート $200 \mathrm{MS} / \mathrm{s}$ のディジタルレコーダと組み合わせて標準測定系を構成し ている。さらに, 測定器の校正のためには出力電圧 10〜 $500 \mathrm{~V}$ の雷及び開閉インパルス電圧発生器を有している ${ }^{(8)}$ 。 この測定システムの測定の不確かさは，95\%信頼水準で，波

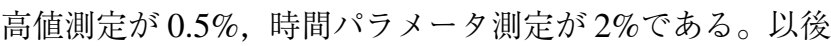
このシステムを NIT システムと表記する。

NMI はオーストラリアの国家標準機関で NATA (National Association of Testing Authorities）の指定校正機関である。 1 ユニットあたり $3.3 \mathrm{k} \Omega$ の高圧部抵抗体 3 本を必要に応じ て直列接続した標準分圧器と，8ビット，500 MS/s の測定 器で構成するオーストラリアの国家標準測定システムであ る。このシステムの測定の不確かさの公表值は，95\%信頼

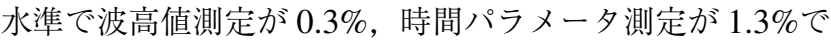
ある。測定器の校正には，独自に開発した雷インパルス電 圧用の校正器を用いている。これらのシステムを以後 NMI
Table 1. Contents of comparison tests.

\begin{tabular}{c|c|c|c}
\hline \multirow{2}{*}{$\begin{array}{c}\text { High } \\
\text { Voltage }\end{array}$} & $\begin{array}{c}\text { Comparison } \\
\text { Test }\end{array}$ & $\begin{array}{c}0.84 / 60 \mu \mathrm{s} \\
1.56 / 60 \mu \mathrm{s}\end{array}$ & $\pm 300 \mathrm{kV} / \pm 400 \mathrm{kV}$ \\
\cline { 2 - 4 } Test & $\begin{array}{c}\text { Linearity } \\
\text { Test }\end{array}$ & $1.56 / 60 \mu \mathrm{s}$ & $\pm 80 \mathrm{kV} \sim 460 \mathrm{kV}$ \\
\hline \multirow{2}{*}{ Low } & & $0.84 / 60 \mu \mathrm{s}$ & \\
Voltage & Comparison & $1.56 / 60 \mu \mathrm{s}$ & $\pm 10 \mathrm{~V} \sim 500 \mathrm{~V}$ \\
Test & Test & $250 / 2500 \mu \mathrm{s}$ & \\
& & $20 / 4000 \mu \mathrm{s}$ & \\
\hline
\end{tabular}

Table 2. Measuring system of each laboratory.

\begin{tabular}{|c|c|c|}
\hline \multirow{3}{*}{ Laboratory } & Type of Divider & Value of Main Resistor \\
\hline & Name of Recorder & $\begin{array}{l}\text { Rated Resolution } \\
\text { Sampling Rate }\end{array}$ \\
\hline & \multicolumn{2}{|c|}{ Calibrator } \\
\hline \multirow{3}{*}{ NIT } & Shielded Resistive & $10 \mathrm{k} \Omega$ \\
\hline & TR-AS 200-12 & $12 \mathrm{bit} 200 \mathrm{MS} / \mathrm{s}$ \\
\hline & \multicolumn{2}{|c|}{$\begin{array}{c}\text { Selfmade } 10 \sim 500 \mathrm{~V} \\
0.84 / 60 \mu \mathrm{s}, 1.56 / 60 \mu \mathrm{s}, 250 / 2500 \mu \mathrm{s}, 20 / 4000 \mu \mathrm{s}\end{array}$} \\
\hline \multirow{3}{*}{ NMI } & Shielded Resistive & $3.3 \mathrm{k} \Omega$ \\
\hline & TDS540C & 8 bit $500 \mathrm{MS} / \mathrm{s}$ \\
\hline & Self-made $\quad 10 \sim 500$ & $0.84 / 60 \mu \mathrm{s}, 1.56 / 60 \mu \mathrm{s}$ \\
\hline \multirow{3}{*}{ KERI } & $\begin{array}{c}\text { Multi Sielded } \\
\text { Resistive }\end{array}$ & $2 \mathrm{k} \Omega$ \\
\hline & TDS540C & 8 bit $500 \mathrm{MS} / \mathrm{s}$ \\
\hline & \multicolumn{2}{|c|}{ Not Used } \\
\hline \multirow{3}{*}{ MITSUBISHI } & Shielded Resistive & $10 \mathrm{k} \Omega$ \\
\hline & PowerPro610 & $10 \mathrm{bit} 75 \mathrm{MS} / \mathrm{s}$ \\
\hline & \multicolumn{2}{|c|}{ Not Used } \\
\hline \multirow{3}{*}{ CRIEPI } & Shielded Resistive & $10 \mathrm{k} \Omega$ \\
\hline & RTD710A & 10bit $100 \mathrm{MS} / \mathrm{s}$ \\
\hline & \multicolumn{2}{|c|}{ Not Used } \\
\hline
\end{tabular}

システムと表記する。

媒介測定系としてNMI と試験を実施した三菱電機株式会 社系統变電システム製作所保有の測定システムは, 高圧部 抵抗体 $10 \mathrm{k} \Omega$ の基準分圧器と 10 ビット, $75 \mathrm{MS} / \mathrm{s}$ のディジ タルレコーダとの構成である。また本システムは, 試験所 認定制度に基づく測定システムとして ISO17025 の認定を 受けた測定系である。以後この測定系を MITSUBISHI シ ステムと表記する。

KERI は韓国最大の高電圧試験研究機関である。1999 年 に実施された国際比較試験で用いられたへルシンキ工科大 学の巡回システムと同型の多重シールド抵抗型分圧器と, NMI と同型の測定器で構成するシステムを有している。こ のシステムは韓国の国家標準測定システムとして運用され る予定にあり，現在測定の不確かさの見積もりが行なわれ ている。以後この測定系を KERI システムと表記する。

媒介測定系として KERI と試験を実施した電力中央研究 所保有の測定システムは, MITSUBISHI と同型の基準分圧 器と 10 ビット, $100 \mathrm{MS} / \mathrm{s}$ のディジタルレコーダとの構成 である。以後この測定系を CRIEPI システムと表記する。 


\section{3. 試験結果}

〈3・1〉高電圧比較試験ＭITSUBISHI システム-NMI システム間の比較試験は, NATA 指定校正機関としての NMI のルーチンワークとして MITSUBISHI システムを校正す るスキームでおこなわれた。まず低圧系のシールドを含め たMITSUBISHI システムを日本から NMI 輸送して, 同 ホール内に独立した測定系を構築した。IEC60060-2 ${ }^{(9)} に$ 従って互いの測定系はインパルス電圧発生器の発生電圧を 同時に印加するよう並列接続した上，接続線を互いに直角 に配置し干渉を最小に抑えた。両システムに電圧を 10 回 印加して, 測定值の平均值と標準偏差を算出した。Table 3 にNMI を基準とした比較試験結果を示す。

ここで $\mathrm{Vp}$ は波高值， $\mathrm{T}_{1}$ は波頭長， $\mathrm{T}_{2}$ は波尾長である。

また，直線性試験は $\pm 96 \mathrm{kV}$ から $\pm 460 \mathrm{kV}$ の間の 5 電圧 で実施した結果，NMI システムに比べて MITSUBISHI シ ステムの測定結果は最大 $0.6 \%$ ぼ波高值の読みの差，つま りスケールファクタ偏差が認められた。

CRIEPI-KERI システム間の比較試験も CRIEPI システ ムを KERI 輸送して実施した。高電圧ホール内に二つの 独立した測定系を構築してNMI で実施した内容と同様の試 験を実施した。ただしシールド測定系は KERI の設備を共 用した。Table 4 にCRIEPI を基準とした試験結果を示す。 直線性試験は， $\pm 80 \mathrm{kV}$ から $\pm 400 \mathrm{kV}$ の範囲において $80 \mathrm{kV}$ ステップで各極性 5 点ずつ実施した。KERI システム

Table 3. Comparison test results between NMI and MITSUBISHI $(\mathrm{NMI}=1)$.

\begin{tabular}{c|c|c|c|c}
\hline & & $\mathrm{Vp}$ & $\mathrm{T}_{1}$ & $\mathrm{~T}_{2}$ \\
\hline \multirow{3}{*}{ Short } & + & 0.994 & 0.985 & 0.996 \\
\cline { 2 - 5 } & - & 0.992 & 0.987 & 0.996 \\
\hline \multirow{3}{*}{ Long } & + & 0.993 & 0.981 & 0.997 \\
\cline { 2 - 5 } & - & 0.991 & 0.980 & 0.996 \\
\hline
\end{tabular}

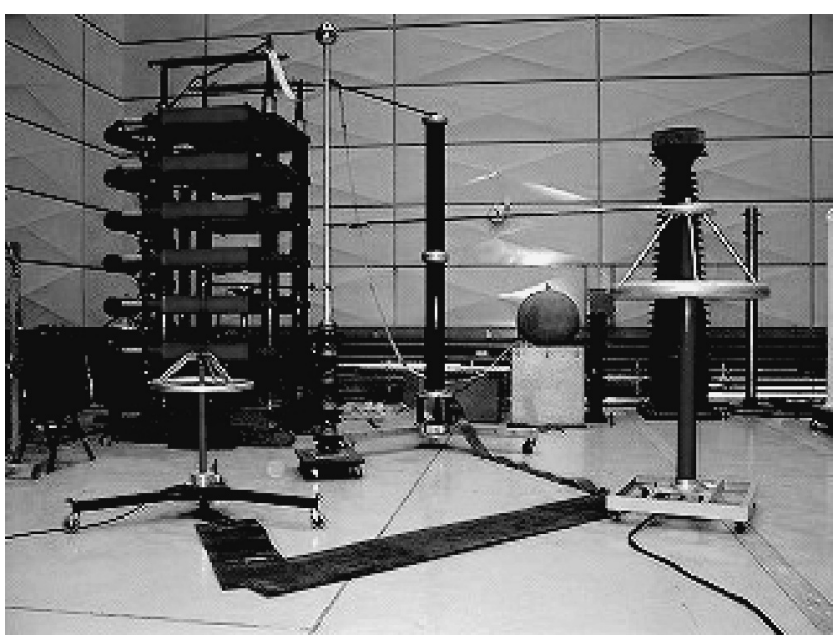

Fig. 1. Comparison test between NMI and MITSUBISHI.
と CRIEPI システム間には最大で $0.36 \%$ のスケールファク 夕偏差が認められた。さらに 2 組の媒介測定系は帰国後 NIT との間で比較試験を行って NMI システムおよび KERI シス テムの NIT に対する偏差を確認した。Fig. 2 にその結果を

Table 4. Comparison test results between CRIEPI and KERI (CRIEPI = 1).

\begin{tabular}{c|c|c|c|c}
\hline & & $\mathrm{Vp}$ & $\mathrm{T}_{1}$ & $\mathrm{~T}_{2}$ \\
\hline \multirow{3}{*}{ Short } & + & 0.9951 & 1.0397 & 1.0240 \\
\cline { 2 - 5 } & - & 0.9894 & 1.0062 & 1.0420 \\
\hline \multirow{3}{*}{ Long } & + & 0.9891 & 1.0129 & 1.0136 \\
\cline { 2 - 5 } & - & 0.9950 & 1.0190 & 1.0157 \\
\hline
\end{tabular}
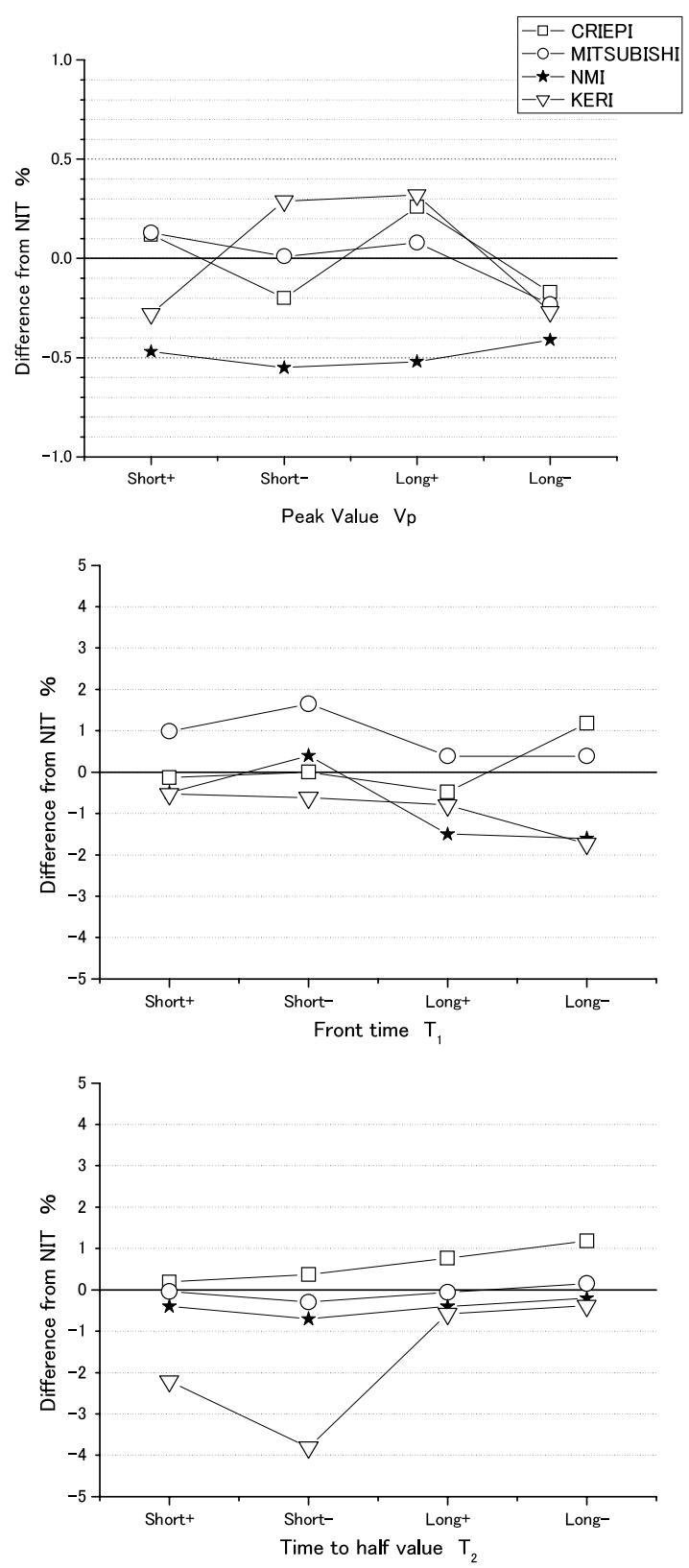

Fig. 2. Wave parameter differences deduced from high voltage comparison test results. 
示す。波高值測定では NMI システムとの間にほぼ $-0.5 \%$, KERI システムとの間には最大 $0.3 \% の$ 偏差が見られた。時 間パラメータ測定では同様に NMI システムに対して最大 $-1.6 \%$, KERI システムに対して最大 $-1.7 \%$ の偏差が見ら れた。

また MITSUBISHI およびCRIEPI 両システムは，帰国 後に実施した校正試験により，NIT との波高值の最大偏差 がそれぞれ MITSUBISHI で $0.23 \%$, CRIEPIで $0.26 \%$ ，ま た時間パラメータの最大偏差は MITSUBISHI で $1.65 \%$, CRIEPI で 1.18\%の值が得られた。これらの測定系間のト レーサビリティに関する厳密な議論については 4 章にて述 べる。なお，KERI システムとの測定については，測定室 内の気温上昇に伴う測定環境の影響によると思われる大き な偏差が得られた。そのため CRIEPI システムの波形解析 ソフトのデー夕補正機能を調整して不確かさが最小となる 条件を求め, さらに国家標準級測定システムとのトレーサ ビリティが維持されるように，その条件のもと，国家標準 級測定システムで CRIEPI システムを校正し，KERI との 偏差を評価した結果，波尾長に $2 \%$ の偏差が認められた。

$\langle\mathbf{3 \cdot 2}\rangle$ 低電圧比較試験 1999 年の国際比較試験で実 施された低電圧比較試験では, 巡回器であるインパルス低電 圧発生器の発生波形をその機関で最高の性能を持つ測定器で 評価する方法が取られた。日本で実施された試験も Table 2 に示す 12 ビット, $200 \mathrm{MS} / \mathrm{s}$ の測定器を用いて評価を行った。 今回の試験では, NMI-NIT 間の比較には MITSUBISHI 測 定器を用いて両機関の校正器出力を印加し, また KERI-NIT 間の比較には KERI 測定器に NIT 校正器出力を印加して相 対比較を実施した。NIT 校正器, NMI 校正器とも出力電圧を 10 回ずつ測定器に印加して，それぞれの測定パラメータの 平均值を求めた。 NIT 校正器の出力電圧を基準とした NMI 校正器の偏差を Fig. 3 (0.84/60 $\mu$ s 雷インパルス電圧), Fig. 4 $(1.56 / 60 \mu \mathrm{s}$ 雷インパルス電圧) および Fig. 5 （250/2500 $\mu \mathrm{s}$ 開閉インパルス電圧) を示す。

短い波頭長（Fig. 3) の比較では，波高值についてはどの 経路もよい一致をみせ，その值は最大でも+50.00 V の比較 時に $0.38 \%$ あったた。波尾長についてもどの経路について もよく一致し，最大で $0.7 \%$ 以内の偏差となった。一方，波 頭長比較については NMI の校正器出力を日本の測定器で

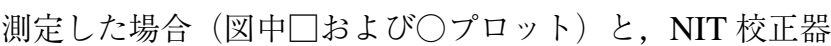
の出力を NMI 測定器および KERI 測定器で測定した場合 （メおよびマプロット）の校正経路間では 3\%ほどの差が見 られた。

また，長い波頭長（Fig.4）の比較では，波高值測定でも 同経路間に平均 $0.5 \%$ 程度の経路間偏差が見られたものの, 時間パラメー夕測定については経路間による差は見られな かった。通常，校正経路の違いによる差が生ずることは考 えられないことから, 校正器の定格出力パラメー夕に変化 があったなど，なんらかの外因によるものと考えられる。 また，経路間偏差が見られなかった結果からは，日豪間の 低電圧標準には，波高值，波尾長はほぼ等しく，波頭長差
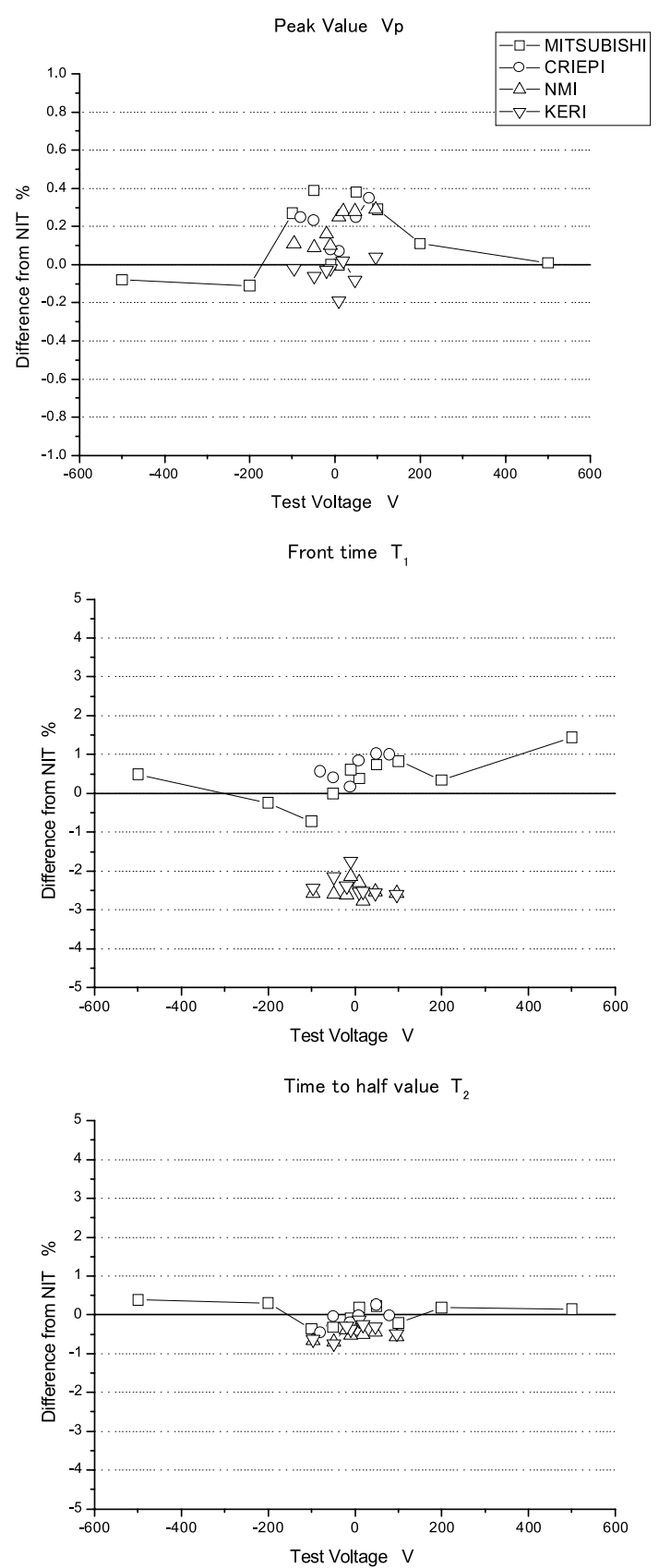

Fig. 3. Comparison test result at low voltage $(0.84 / 60 \mu \mathrm{s})$ $(\mathrm{NIT}=1)$.

は $2 \%$ 程度あることがわかった。

開閉インパルス電圧については, NMI および KERI で校 正器を所有していないため, NIT 校正器により NMI 測定器 およびKERI 測定器で測定した結果のみを示す。標準開閉イ ンパルス電圧 $(250 / 2500 \mu \mathrm{s})$ の波高值偏差は, NIT-NMI 間 では $0.1 \%$ 程度で一致したが, NIT-KERI 間では最大 $0.4 \%$ の 差が生じた。KERI 測定器は NMI にトレースしているが, 長期的な測定器の変動により，若干校正值がずれたのでは ないかと考えられる。

開閉インパルス電圧の波頭長は，原点から真の波高点ま での時間と定義されており，その最短值は $20 \mu \mathrm{s}$ である。 また標準開閉インパルス電圧波形として定義される波尾長 

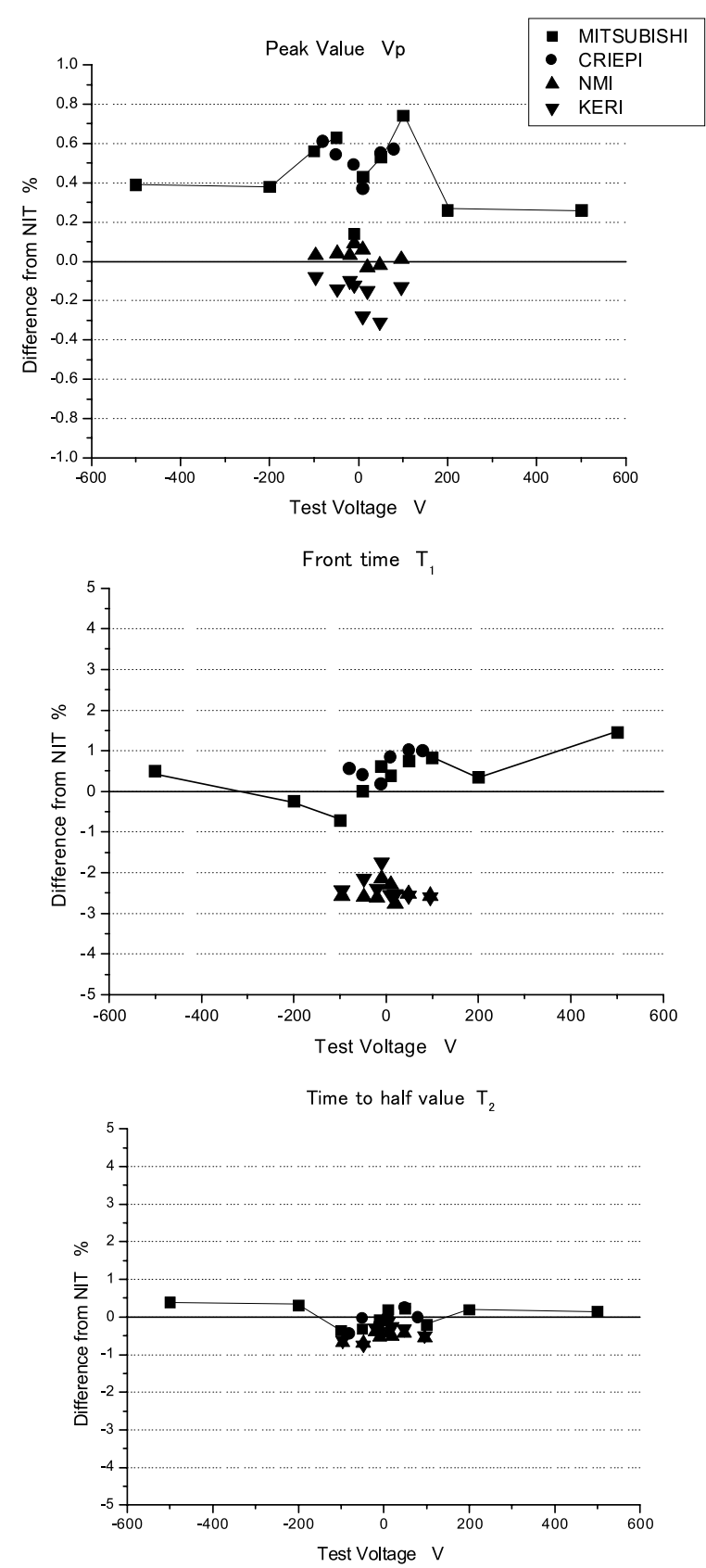

Fig. 4. Comparison test result at low voltage $(1.56 / 60 \mu \mathrm{s})$ $(\mathrm{NIT}=1)$.

$2500 \mu \mathrm{s}$ は裕度 $\pm 60 \%$ が認められているため, その最大值は $4000 \mu \mathrm{s}$ となる。これらの組合せである $20 / 4000 \mu \mathrm{s}$ 波形を 用いた試験も実施した。同波形は急峻に立ち上がり，平坦 な波高部が続く解析が困難な波形である。この場合, ディ ジタル測定では, 分解能による量子化誤差のため, 波高付 近は長く一定值を示し続け，正確に波高点に達する時間の 決定は困難である。わが国では雷インパルス電圧の定義と 同様に 30\%波高点および $90 \%$ 波高点の時間間隔から決定

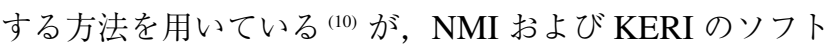
ウェアでは，一定值の中心值を波高点として算出している。

このため試験結果は波高值で $0.2 \%$, 波頭長では $10 \%$ 以 上もの偏差が得られた。
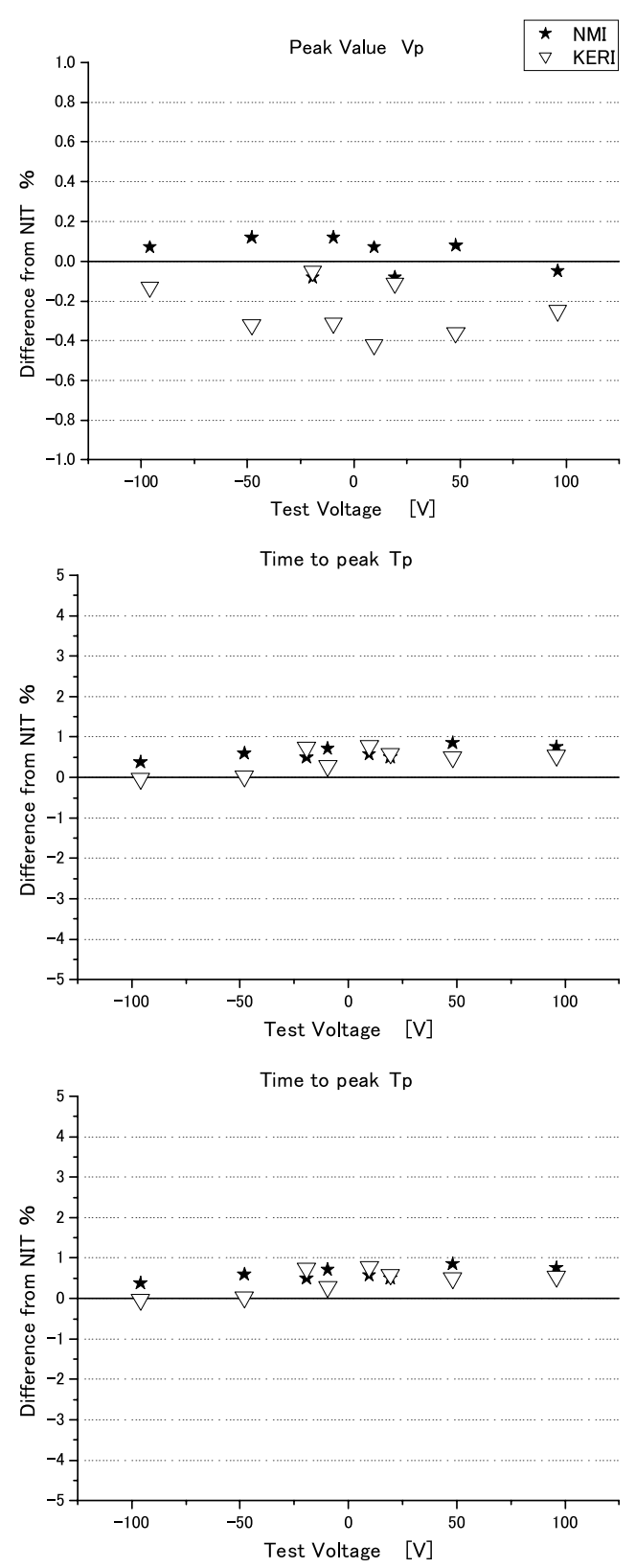

Fig. 5. Comparison test result at low voltage $(250 / 2500 \mu \mathrm{s})$ $(\mathrm{NIT}=1)$.

\section{4. 測定の不確かさと同等性の検証}

〈4・1〉高電圧比較試験 インパルス測定系はその周 波数特性のため, 直流電圧を印加して決定するDC スケー ルファクタと, インパルス電圧を測定するために用いるイ ンパルススケールファクタとでは，一般にその值が異なる。 そのため校正試験において, 校正機関はトレーサビリティ を担保するために, 自己の標準測定系のインパルススケー ルファクタを基に, 被校正測定系に対して指定スケールファ クタという校正值を与える。

この校正值は，校正機関が持つ測定能力の限界内で与え た值であるため, 校正值は真值に対していくらかの誤差を もつ。この能力を表現するために従前は「精度」などの用 
語が用いられていたが，国際整合化を背景に，測定の信頼 性を表す用語として最近ではほぼ同義の「不確かさ」が用 いられている。

MITSUBISHI システムは, 従来の NITへのトレースの ほかに，本試験により NMIへのトレースも得ることがで きた。ここで本項では, 測定の信頼性を評価するために, MITSUBISHI システムの NMI システムに対する測定の不 確かさを明確にするとともに両経路による值を比較して NIT の測定の不確かさの推定の妥当性を検討する。

NIT にトレースする MITSUBISHI システムの測定の不 確かさは，帰国後に実施した確認試験で得られた 2003 年か ら 2004 年のスケールファクタの変動を考慮すると $95 \%$ 信 頼水準 $(2 \sigma)$ で波高值測定に対して $0.76 \%$ ，時間パラメー 夕測定に対して $2.6 \%$ ，指定スケールファク夕 20,778 とい う值が得られた。

また, 本論文で述べる試験で得られた NMI に対する MITSUBISHI システムの測定の不確かさは，波高值測定の不確 かさ $0.758 \%$, 時間パラメータ測定の不確かさ $1.9 \%$ および指 定スケールファクタ 20,887 となった。ここで二つのスケー ルファクタの差異の妥当性を検討する。相互の測定システ ムの測定の不確かさから得られる合成不確かさの值 $u_{a U p}$ は

$$
u_{a U p}=\sqrt{0.76^{2}+0.758^{2}}
$$$$
=1.07 \%
$$

であり，一方スケールファクタの差異の $D_{S F}$ は

$$
D_{S F}=\frac{20778-20887}{20778}
$$$$
=0.52 \%
$$

であるから，それぞれのスケールファクタの差は測定系の 性能内での偏差であることがわかる。また，時間パラメー 夕についても同様に, 両測定システムの測定の不確かさか ら得られる合成不確かさの值 $u_{a T}$ は

$$
\begin{aligned}
u_{a T} & =\sqrt{2.6^{2}+1.9^{2}} \\
& =3.3 \% \ldots \ldots \ldots
\end{aligned}
$$

であり，波形 $1.56 / 60 \mu \mathrm{s}$ 負極性時の試験で得られた最大偏 差の值

$$
0.39 \%-(-1.60 \%)=1.99 \%
$$

を十分包含することから，得られた試験結果は相互の測定 系の性能内での偏差であることがわかる。

$\langle\mathbf{4} \cdot \mathbf{2}\rangle$ 低電圧比較試験低電圧比較試験では, 媒介測 定器を用いた試験のほかに国家標準級の校正器と測定器と で直接試験を実施することができた。ここでは波高值比較 で最も偏差が大きかった+50.00 V の比較を通して, 両試験 の不確かさを評価し，互いの同等性を検証することとする。

NIT 校正器の発生電圧の不確かさの公表值は $0.3 \%$ ある。 これより,く3・2〉節に従った試験結果から算出したNITにト
レースする MITSUBISHI 測定器の不確かさは, $0.302 \%$ と

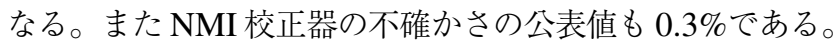
試験から算出したNMI にトレースする MITSUBISHI 測定 器の不確かさは，0.304\%となった。

ここで, 相互の不確かさから得られる合成不確かさの值 $u_{b U p}$ は,

$$
\begin{aligned}
u_{b U p} & =\sqrt{0.302^{2}+0.304^{2}} \\
& \simeq 0.43 \%>0.38 \%
\end{aligned}
$$

であるから, 両校正器の偏差 $0.38 \%$ は性能内での偏差内に あり，低電圧系での同等性が確認される。

また, NIT 校正器を NMI 測定器に直接印加して比較する 試験では, 波高值の差異は平均 $0.11 \%$ ありり, 最も両者の 差が大きい值を示したケースは波形 $0.84 / 60 \mu \mathrm{s}$ で+96.00 V

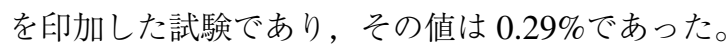

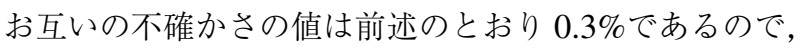
相互の合成不確かさを計算するまでもなく，両者の值はよ く一致したことがわかる。

以上のことから， NIT と NMI システム間にはお互いの 不確かさの能力範囲内で同等性があると確認された。

\section{5. まとめ}

本論文では，2004 年に実施したアジア太平洋圈でのイ ンパルス電圧測定システムの国際比較試験についてその結 果を報告するとともに, 標準測定系の性能について検討を 行った。その結果以下の知見が得られた。

（1）インパルス電圧の標準測定系の国際比較試験を通 して，国際間における電圧パラメー夕の差異を明確にする とともに標準測定系間の同等性が確認できた。

（2）低電圧比較試験においても，測定器を媒介した試 験方法と標準器同士を直接評価する試験の両者で, 標準器 間の同等性が確認できた。高電圧の比較試験においても標 準測定系を直接比較することによってさらに精度の高い比 較試験結果が得られることが期待される。

（3）豪州国家標準にて校正された基準測定システムの 測定の不確かさを算出し, 標準測定系で校正した值と同等 の值が得られることを示した。

今回日本がコーディネータとなって実施したインパルス 電圧測定系の国際比較試験の成功によって，わが国の標準 測定系として運用されているインパルス電圧標準測定系に 必要かつ重要なデー夕を蓄積することができた。アジア・ 太平洋地域の中心的役割を担っていくために今後も定期的 に同様な試験の実施を行い，標準測定系の維持・運用にあ たる必要がある。

なお，本研究は経済産業省の委託事業により行われたも のである。本研究の遂行にあたり, 経済産業省, 日本電機 工業会, オーストラリア政府, 韓国政府をはじめとして, 多 大な協力をいただいた関係各位に謝意を表する。

(平成 18 年 1 月 16 日受付，平成 18 年 8 月 25 日再受付) 


\section{文献}

(1) T. Harada, T. Wakimoto, M. Saeki, and S. Sato: "Development of Performance Impulse Measuring System”, 1999 National Convention Record IEE Japan, Vol.7, pp.191-192 (1999) (in Japanese)

原田達哉・脇本隆之・佐伯正盛・里 周二：「インパルス電圧高精 度測定システムの開発」, 平成 11 年電気学会全国大会 1744, Vol.7, pp.191-192 (1999)

(2) T. Harada, T. Wakimoto, S. Sato, and M. Saeki: "Development of national standard class reference divider for impulse voltage measurements", 11th International Symposium of High Voltage, Vol.1, pp.13-16 (1999)

(3) T. Harada, T. Wakimoto, S. Sato, and M. Saeki: "Development of Japan's National Standard Class $500 \mathrm{kV}$ Lightning Impulse Voltage Divider", IEEE Power Engineering Society 2000 Winter Meeting, Vol.3, pp.1564-1568 (2000)

(4) J. Hallstrom, M. Aro, Y. Zhang, B. Larzelere, J. Fitzpatrick, N. Rivest, L. Lavalee, and T. Wakimoto: "Progress of Worldwide Comparison of Lightning Measuring Systems-Round 1", 12th International Symposium of High Voltage Engineering, 7-1 (2001)

(5) M. Ishii and H. Koyama: "100 kV Class Intercomparison of Impulse Voltage Dividers in Japan”, T. IEE Japan, Vol.114-B, No.1, pp.91-97 (1994-1) (in Japanese)

石井 勝・小山 博: 「100 kV 級雷インパルス電圧による分圧器の 国内持ち回り比較試験」,電学論 B, 114, 1, pp.91-97 (1994-1)

(6) M. Ishii, H. Murase, H. Koyama, and S. Nishimura: "Experience of MV Class Intercomparison Test for Impulse Measuring Systems in Japan", 10th International Symposium of High Voltage Engineering, Vol.4, pp.25-28 (1997)

(7) T. Wakimoto, T. Harada, M. Saeki, and S. Nishimura: "Traceability and Uncertainty for Impulse Voltage Measuring System", 2001 National Convention Record IEE Japan, 7-120, pp.2990-2991 (2001) (in Japanese) 脇本隆之・原田達哉・佐伯正盛・西村誠介：「インパルス電圧測定シ ステムのトレーサビリティと不確かさ」, 平成 13 年電気学会全国大 会, 7-120,pp.2990-2991 (2001)

(8) T. Wakimoto, T. Harada, S. Sato, M. Saeki, and H. Shimizu: "Development of Impulse Calibrator and Its Performance Evaluation", T. IEE Japan, Vol.122-B, No.12, pp.1424-1428 (2002-12) (in Japanese) 脇本隆之・原田達哉・里 周二・佐伯正盛・清水博幸 :「インパルス 校正器の開発と性能評価」, 電学論 B, 122, 12, pp.1424-1428 (2002-12)

(9) IEC60060-2: High-voltage test tequniques, Part 2. Measuring Systems (1994)

(10) T. Wakimoto, T. Harada, and M. Saeki: "High Precision Determination Methods of Time to Peak of Switching Impulse Voltage", T. IEE Japan, Vol.118-B, No.5, pp.548-554 (1994-5) (in Japanese)

脇本隆之・原田達哉・佐伯正盛:「開閉インパルス電圧の高精度波頭 長計算法の提案」, 電学論 B, 118, 5, pp.548-554 (1994-5)

脇 本 隆 之 (正員) 1987 年佐賀大学理工学部電気工学科卒

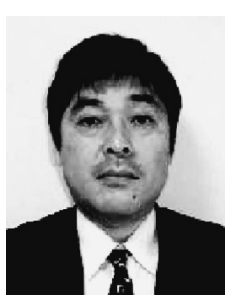
業。1989 年佐賀大学理工学研究科修士課程修了。 1990 年点工業高等専門学校電気工学科助手。1995 年日本工業大学超高圧放電研究センター助手を経 て現在同大学専任講師。主に高電圧計測の研究に 従事。1998 年電気学会優秀論文発表賞受賞。IEEE 会員。

石 井勝 (上級会員) 1971 年東京大学工学部電気工学科

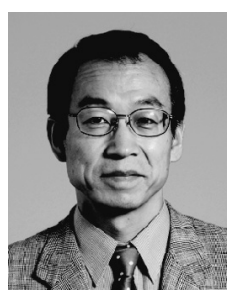
卒業。1976 年東京大学大学院博士課程修了。工学 博士。同年東京大学助教授，生産技術研究所勤務。 1984 年 1986 年マサチューセッツ工科大学客員 研究員。1992 年東京大学教授, 生産技術研究所勤 務，現在に至る。主として系統絶縁，雷，高電圧 測定の研究に従事。2004 年〜2006 年 (社) 電気学 会電力エネルギー部門長。現在，同学会理事。CIGRE SC C4 国内分科会委員長。CIGRE Advisory Group C4.4 (Lightning) Convener。1998 年電気学会進歩賞。1999 年同論文賞。IEEE Fellow, AGU, CIGRE, 電気設備学会, 気象学会等会員。

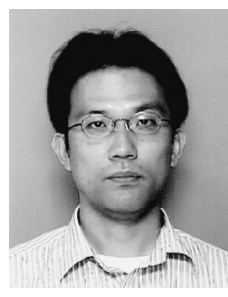

（正員） 1969 年 9 月 12 日生。1996 年 3 月名古 屋大学大学院工学研究科電気工学専攻博士課程後 期課程修了。同年 4 月（財）電力中央研究所入所, 現在に至る。主としてガス絶縁機器の絶縁技術, 雷放電に伴う電磁界現象に関する研究に従事。博 士 (工学)。2005 年〜2006 年ドイッ・ハノーバー 大学客員研究員。1996 年および 2005 年電気学会 論文賞受賞。

日 野 悦 弘 (正員) 1965 年 12 月 14 日生。1988 年 3 月関

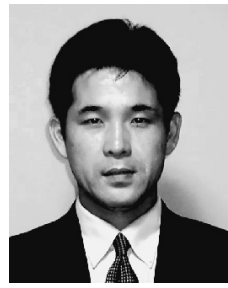
西大学工学部電子工学科卒業。同年 4 月三菱電機 （株）入社。現在，系統変電システム製作所技術 開発部にて高電圧技術開発ならびに高電圧試験所 の運営管理に従事。高電圧試験標準特別委員会幹 事補佐。

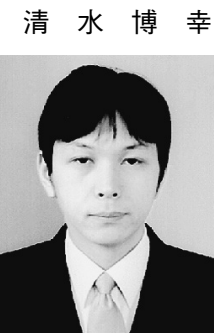

（正員） 1976 年 8 月 15 日生。 2001 年 3 月日本 工業大学大学院工学研究科電気工学専攻博士前期 課程修了。同年 4 月日本工業大学超高圧放電研究 センター助手。 2005 年 4 月同大学院工学研究科 電気工学専攻博士後期課程入学, 現在に至る。主 として, 高電圧計測, 電気電子機能材料の研究に 従事。

Yi Li （非会員） obtained his Ph.D. degree in Physical Science from

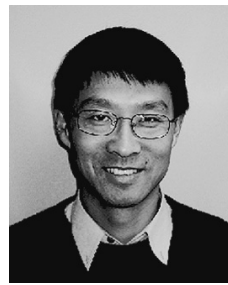
University of Technology Sydney in 1993. He joint the former Division of Applied Physics of Commonwealth Scientific and Industrial Research Organisation of Australia in the same year as a postdoctoral fellow working in the areas of high voltage measurement techniques and applied dielectrics. He has since worked in the same laboratory, now part of the newly formed National Measurement Institute, as a research scientist and then as a principal research scientist. His current areas of research are digital impulse voltage measurement and precision DC high voltage measurement. Dr. Yi $\mathrm{Li}$ is a senior member of IEEE.

Kim Ik-Soo （非会員） was born in Korea on Sept. 20, 1957. He

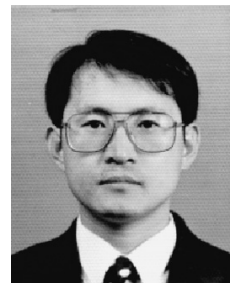
received the M.S. and Ph.D. degree in electrical engineering from Pusan University in 1983 and 2000, respectively. Since 1983, he has been with KERI, as principal research engineer in reliability assessment and certification department. His research interests are high voltage measurement and reliability assessment. 